\title{
Morphometric analysis of the placenta in the New World mouse Necromys lasiurus (Rodentia, Cricetidae): a comparison of placental development in cricetids and murids
}

Phelipe O Favaron ${ }^{1 *}$, Andrea M Mess ${ }^{1}$, Moacir F de Oliveira², Anne Gabory ${ }^{3,4}$, Maria A Miglino ${ }^{1}$, Pascale Chavatte-Palmer ${ }^{3,45}$ and Anne Tarrade $3,4,5$

\begin{abstract}
Background: Stereology is an established method to extrapolate three-dimensional quantities from two-dimensional images. It was applied to placentation in the mouse, but not yet for other rodents. Herein, we provide the first study on quantitative placental development in a sigmodontine rodent species with relatively similar gestational time. Placental structure was also compared to the mouse, in order to evaluate similarities and differences in developmental patterns at the end of gestation.
\end{abstract}

Methods: Fetal and placental tissues of Necromys lasiurus were collected and weighed at 3 different stages of gestation (early, mid and late gestation) for placental stereology. The total and relative volumes of placenta and of its main layers were investigated. Volume fractions of labyrinth components were quantified by the One Stop method in 31 placentae collected from different individuals, using the Mercator ${ }^{\circledR}$ software. Data generated at the end of gestation from N. lasiurus placentae were compared to those of Mus musculus domesticus obtained at the same stage.

Results: A significant increase in the total absolute volumes of the placenta and its main layers occurred from early to mid-gestation, followed by a reduction near term, with the labyrinth layer becoming the most prominent area. Moreover, at the end of gestation, the total volume of the mouse placenta was significantly increased compared to that of N. lasiurus although the proportions of the labyrinth layer and junctional zones were similar. Analysis of the volume fractions of the components in the labyrinth indicated a significant increase in fetal vessels and sinusoidal giant cells, a decrease in labyrinthine trophoblast whereas the proportion of maternal blood space remained stable in the course of gestation. On the other hand, in the mouse, volume fractions of fetal vessels and sinusoidal giant cells decreased whereas the volume fraction of labyrinthine trophoblast increased compared to N. lasiurus placenta.

Conclusions: Placental development differed between N. lasiurus and M. musculus domesticus. In particular, the low placental efficiency in N. lasiurus seemed to induce morphological optimization of fetomaternal exchanges. In conclusion, despite similar structural aspects of placentation in these species, the quantitative dynamics showed important differences.

Keywords: Placenta, Stereology, Sigmodontinae, Decidua, Junctional zone, Labyrinth, Haemochorial placenta, Fetal vessels, Trophoblast, Evolution

\footnotetext{
* Correspondence: phelipe.favaron@yahoo.com.br

'Department of Surgery, School of Veterinary Medicine, University of Sao Paulo, Av. Prof. Dr. Orlando Marques de Paiva, 87, Cidade Universitária, São Paulo, SP CEP 05508-270, Brazil

Full list of author information is available at the end of the article
} 


\section{Background}

Stereology is a well-established method to extrapolate three-dimensional structural quantities from measurements on two-dimensional sectional images by using a randomized design-based approach [1,2]. It facilitates interpretations of normal and abnormal structure from a whole organ to the subcellular level [3]. Besides other organs, this approach has been used to investigate the development of placental tissues with special reference to the feto-maternal exchanges in the human placenta $[3,4]$. Stereology contributed to clarify key issues on normal and perturbed morphogenesis in human placentation [4-8], but this method has been also applied to placentation in animal species such as the mouse [9], the bovine, including cloned specimens $[10,11]$, the horse [12-14] and non-human primates $[15,16]$.

Rodents, Mus musculus in particular, using knock-out or targeting gene technologies, have improved our understanding on placental development and consequently on human placentation [17-20]. However, studies on quantitative aspects of normal placentation and pathological aspects are rare and refer only to the mouse [9,21-31]. Indeed, structural data on placental development are available in the mouse [18,32-37] and near relatives such as the rat [38]. Investigations in Cricetidae including New World mice or Sigmodontinae [39-44], which are close relatives of Muridae, indicated that structural aspects of placentation represented a largely conserved pattern. The chorioallantoic placenta in both groups is discoidal and organized into labyrinth, junctional zone and decidua (Figure 1A,B). Moreover, the fetomaternal interface inside the labyrinth is defined as haemochorial type (Figure $1 \mathrm{C}$ ). We herein provide the first study on the quantitative development of main placental regions in a sigmodontine rodent of South American savannas. Necromys lasiurus is a small cricetid rodent commonly known as hairy-tailed akodont broadly distributed throughout South America. The average litter size is 3-6 pups and their birthweight is $2 \mathrm{~g}$ [45]. Special reference is drawn to the development of volume quantities of placental layers and components of the labyrinth as area of nutrient exchange from maternal to fetal side. As the gestational period is 23 days in $N$. lasiurus [45] and 19 days in $M$. musculus domesticus, M. musculus placentae collected at the end of gestation were included in our study to determine functional significances related to quantitative changes during late gestation and to find out if both taxa have similar patterns of quantitative development.

\section{Methods}

\section{Animals}

Altogether 31 placentae of $N$. lasiurus were obtained from a breeding group at the Universidade Federal Rural do Semi-Árido, Mossoró, Brazil. The project was approved by the Bioethic Commission of the School of Veterinary Medicine and Animal Science, University of São Paulo (Protocol number 1766/2009). The material covered three gestational phases, i.e. early gestation $(10-13$ days, $n=14)$, mid gestation (15-16 days, $\mathrm{n}=9)$ and near term $(21-22$ days, $n=8)$. Gestational age was estimated by using crown-rump lengths (CRL) of fetuses in comparison to published data on the mouse [46]. Fetuses and placentae were weighed and the placental efficiency (fetal weight/ placental weight) were calculated (Table 1). For comparison, four mouse placentae (Mus musculus domesticus, C57Bl/6 × DBA2, Harlan Laboratories, Netherlands) collected at 15.5 days of gestation (exactly date of pregnancy) at the INRA were investigated by the same methods.

\section{Histology and immunohistochemistry}

Placentae were fixed in $10 \%$ formalin, dehydrated in ethanol solutions of increasing concentration, cleared in xylene, embedded in paraplast and sectioned at $5 \mu \mathrm{m}$ (Leica RM2155 microtome, Germany). In early stages of pregnancy, fetal erythrocytes are nucleated, thus the fetal and maternal blood systems inside the labyrinth were distinguishable using histological sections stained with haematoxylin and eosin (see Figure 1C). In mid and late gestation, the absence of erythroblasts in the fetal vessels lead us to use immunodetection of vimentin. For this, sections were incubated with the primary antibody (1:200; Clone V9, Millipore, France) overnight at $4^{\circ} \mathrm{C}$. After several washed, a biotinylated secondary antibody (1:500, biotin donkey anti-mouse, Interchim, Montluçon, France) was applied for $1 \mathrm{~h}$ at $37^{\circ} \mathrm{C}$. Sections were rinsed in PBS $(3 \times 5 \mathrm{~min})$ and incubated for $30 \mathrm{~min}$ in a Vectastain $\mathrm{ABC}$ kit (Vector Laboratories, Burlingame, California) to amplify the staining, as described by Lecarpentier et al. [47]. The immunoreactivity was visualized using a DAB chromogen with $2 \%$ of hydrogen peroxide ammonium nickel for $10 \mathrm{~min}$. Sections were counterstained with toluidine blue and mounted in Eukitt (Sigma Aldrich).

\section{Stereological analysis}

For Cavalieri volume estimation, 3 placentae from early and late gestation and 4 placentae from mid-gestation were used. A series of transversal cross-sections was generated for each placenta. Every $60^{\text {th }}$ section was kept and stained. Stained sections were scanned using a NanoZoomer Digital Pathology System (NDP Scan U10074-01, Hamamatsu, Japan) to produce full panoramic views. The total volumes of the placenta and its compartments i.e., labyrinth, junctional zone, and decidua were determine using the Cavalieri method [2] available on Mercator ${ }^{\circledR}$ software. Each compartment was rigorous outlined manually. 


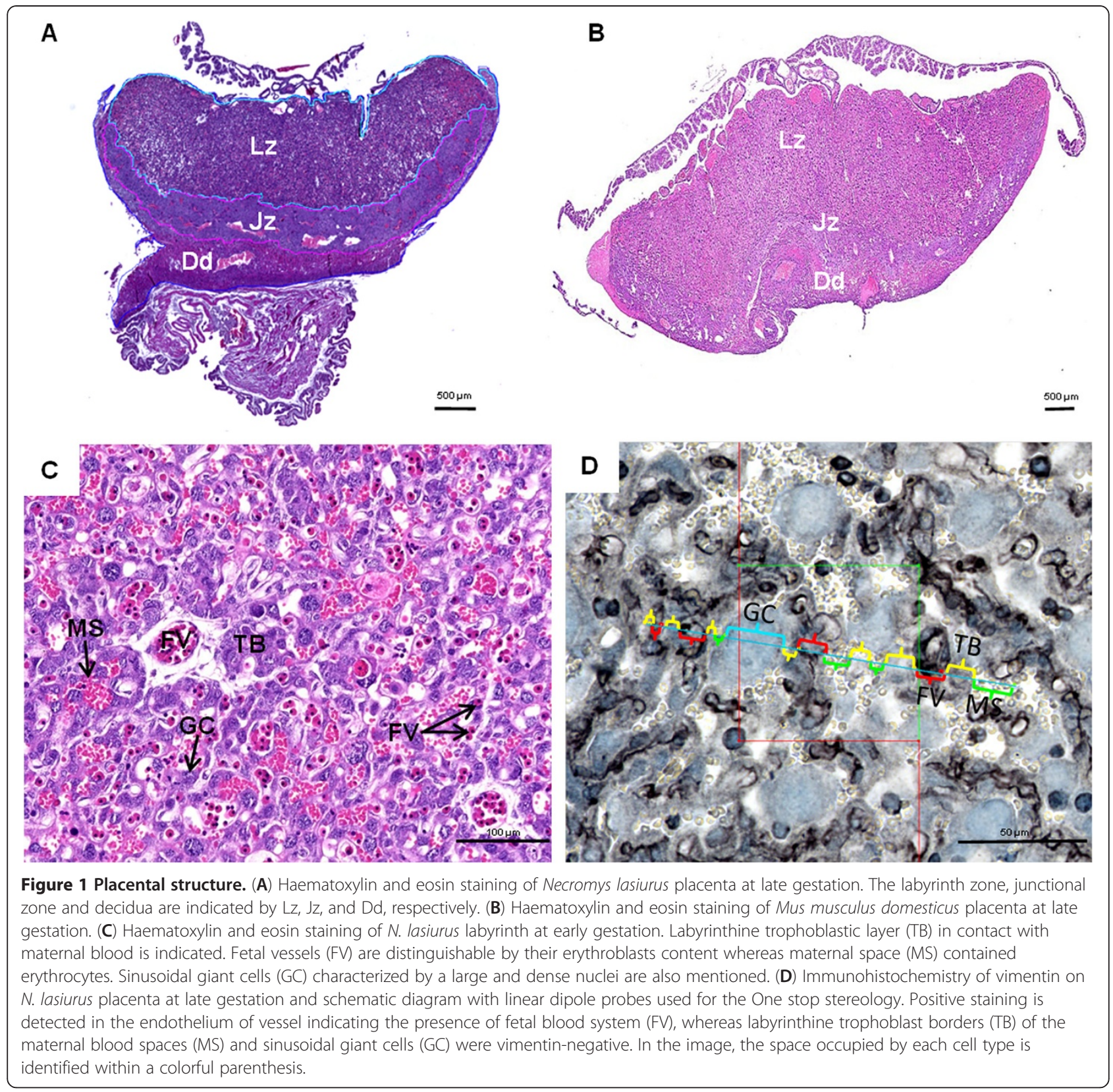

Volume fractions of all the components of the labyrinth area i.e., fetal vessels, sinusoidal giant cells, labyrinthine trophoblast, and maternal blood compartments were quantified by One Stop Stereology using the Mercator ${ }^{\circledR}$ software [48], according to gestational age. For this part, 31 vertical uniform random sections of placenta were used after vimentin immunodetection. Using the software Mercator $^{\circledR}$, the labyrinth region was outlined manually. Then, around 40-50 probe estimator per section were analyzed as showed in the Figure 1D. The intersection of each categories of cells with the probe estimator was evaluated. In addition, the volume density was automatically calculated by the software.

\section{Statistical analysis}

Statistical analysis was performed using Graphpad Prism ${ }^{\circledR}$. Kruskall-Wallis was used follow by Dunn's multiple comparison test. $\mathrm{p}<0.05$ was considered as statistically significant. All results are expressed as means $\pm \mathrm{SD}$.

\section{Results}

Fetal and placental weights of $N$. lasiurus were determined during gestation (Table 1). As expected, their weight increased throughout the gestation by 12.4- and 17.8-fold from early to late gestation, respectively. Moreover the fetal to placental weight ratio, a marker of placental 
Table 1 Fetal and placental weights $(\mathbf{g})$ and feto-placental weight ratio regarded as placental efficiency in Necromys lasiurus (Rodentia, Cricetidae) during gestation*

\begin{tabular}{|c|c|c|c|c|c|c|c|}
\hline & \multicolumn{3}{|c|}{ Early gestation } & \multicolumn{2}{|c|}{ Mid gestation } & \multicolumn{2}{|c|}{ Near term placenta } \\
\hline & 10 days $n=4$ & 11 days $n=5$ & 13 days $n=5$ & 15 days $n=4$ & 16 days $n=5$ & 21 days $n=4$ & 22 days $n=4$ \\
\hline Fetal weight (g) & $0,0835 \pm 0,02043$ & $0,1068 \pm 0,01660$ & $0,1028 \pm 0,01307$ & $0,5458 \pm 0,01586$ & $0,5728 \pm 0,01504$ & $0,9733 \pm 0,05138$ & $1,038 \pm 0,06650$ \\
\hline Placental weight (g) & $0,05175 \pm, 00725$ & $0,0582 \pm, 008766$ & $0,0680 \pm, 005805$ & $0,0900 \pm 0,01235$ & $0,1282 \pm 0,02183$ & $0,8650 \pm, 007382$ & $0,9213 \pm 0,02186$ \\
\hline Feto/Placental (g) & $0,7530 \pm 0,1867$ & $0,5807 \pm 0,08380$ & $0,7383 \pm 0,1744$ & $0,7977 \pm 0,01580$ & $0,8323 \pm 0,02759$ & $0,8947 \pm 0,03743$ & $0,9025 \pm 0,07867$ \\
\hline
\end{tabular}

* Gestational age was estimated according to Evans and Sack (1973).

efficiency, increased by 1.19 -fold throughout gestation and reached a maximum at 22 days of gestation.

During all gestational stages $N$. lasiurus showed a chorioallantoic placenta organized in three main layers, i.e. the labyrinth, junctional zone and decidua (Figure 1A) like in the Mus musculus domesticus (Figure 1B). In the labyrinth, trophoblastic layers (cellular and syncytial), i.e. labyrinthine trophoblast separated maternal and fetal circulations. Whereas, sinusoidal giant cells (one subtype of trophoblast) which showed large size and nuclei were distributed largely in the labyrinth (Figure $1 \mathrm{C}$ and D). The junctional zone had a folded structure composed by cellular and syncytial trophoblast and giant cells. In closely contact to the junctional zone, the decidual cells and maternal spiral arteries formed a decidual layer which was attached to the uterus (Figure 1A).

Total and relative volumes of the placentae and of the main layers throughout gestation were estimated by stereology (Figure 2).

\section{Absolute volumes}

A significant increase occurred in the absolute placental volume from early $\left(4.43 \pm 0.282 \mathrm{~mm}^{3}\right)$ to mid-gestation $\left(12.98 \pm 1.305 \mathrm{~mm}^{3}, \mathrm{p}<0.05\right)$, then the volume decrease from mid to late-gestation $\left(7.52 \pm 0.155 \mathrm{~mm}^{3}\right)$ (Figure 2A). Interestingly, the absolute placental volume of $M$. musculus domesticus was 2.87-fold higher than those of $N$. lasiurus at the end of gestation. The absolute volumes of the labyrinth and junctional zones and decidua followed the same trend than the absolute placental volume (Figure 2A). In fact, the labyrinth increased significantly its total volume from $2.17 \pm 0.078 \mathrm{~mm}^{3}$ in early gestation to $7.03 \pm 0.945 \mathrm{~mm}^{3}$ in mid-gestation $(\mathrm{p}<0.05)$, followed by a decrease to $4.47 \pm$ $0.440 \mathrm{~mm}^{3}$ near term (Figure $2 \mathrm{~A}$ ). The total volume of the junctional zone was enlarged from $0.78 \pm 0.155 \mathrm{~mm}^{3}$ in early pregnancy to $2.82 \pm 1.220 \mathrm{~mm}^{3}$ in mid gestation $(\mathrm{p}<$ 0.05 ) and decreased to $1.67 \pm 0.481 \mathrm{~mm}^{3}$ near term (Figure 2A), whereas the total volume of the decidua remained stable throughout the gestation (1.47 \pm $0.545 \mathrm{~mm}^{3}$ at early stage, $3.122 \pm 0.913 \mathrm{~mm}^{3}$ at midgestation and $1.37 \pm 0.270 \mathrm{~mm}^{3}$ near term) (Figure 2A). In M. musculus domesticus placenta, the absolute volumes of the labyrinth and junctional zone were closed and

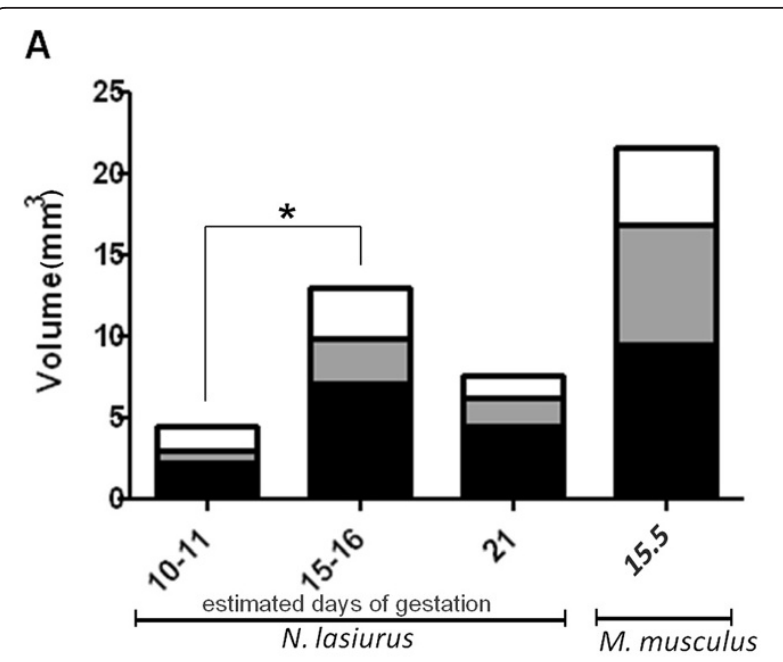

B

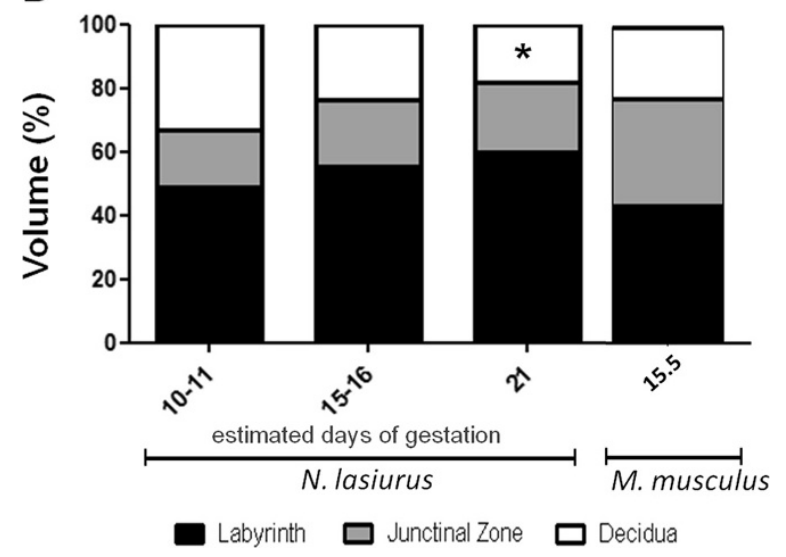

Figure 2 Volume of Necromys lasiurus placenta and of three main layers according to the time of gestation. (A) Total volumes of placenta and of main layers during gestation in $\mathrm{N}$. lasiurus and in Mus musculus domesticus at 15.5 days of gestation. A significant difference $(p<0.05)$ was observed in the total volume of the placenta, and in the labyrinth and junctional zone layers between $10 / 11$ and 15/16 days of gestation. There were no statistically significant differences in relation to the volume of the decidua during the gestation. (B) Relative volumes of placenta and of main layers during gestation in N. lasiurus and $M$. musculus near the term. $\left(^{*}\right)$ indicates a significant difference in the volume of decidua between the days $10 / 11$ and 21 days of gestation $(p<0.05)$. The total volumes of each layer were determined using the Cavalieri method as described in material and methods. 
represented $9.429 \pm 1.633$ and $7.382 \pm 2.142 \mathrm{~mm}^{3}$, respectively, in late pregnancy.

\section{Relative volumes}

Relative volume was determined to compare the proportion of each layer at each time of gestation in both $N$. lasiurus and M. musculus domesticus placentae (Figure 2B). In $N$. lasiurus, the labyrinth was the most prominent placental layer compared to the junctional zone and to the decidua, especially at the end of gestation when fetal growth is higher. Significant differences $(\mathrm{p}<0.05)$ was found in the relative volume of decidua between 10/11 and 21 days of gestation. In contrast, in $M$. musculus domesticus the proportion of labyrinth layer and junctional zone were similar.
The volume fractions of the main components in the labyrinth zone during gestation are represented in (Figure 3). A continuous increase in the volume fraction of fetal vessels occurred from day $10(7.38 \pm 0.49 \%)$ to day $22(34.05 \pm 0.87 \%, \mathrm{p}<0.01)$ (Figure $3 \mathrm{~A})$. The volume fraction of sinusoidal giant cells followed the same trend from early pregnancy $(6.11 \pm 0.84 \%)$ to late gestation $(19.26 \pm 1.34 \%, \mathrm{p}<0.01)$ (Figure 3B). In contrast, the volume fraction of the labyrinthine trophoblast was increased in early and mid-gestation $(59.29 \pm 2.21 \%$ and $37.29 \pm 1.01 \%$ respectively) and decreased significantly at 21 days of gestation $(21.16 \pm 0.65 \%, \mathrm{p}<0.01)$ (Figure $3 \mathrm{C}$ ). The volume fraction of maternal blood spaces did not undergo significant variation throughout pregnancy (Figure 3D). In M. musculus domesticus placentae at day

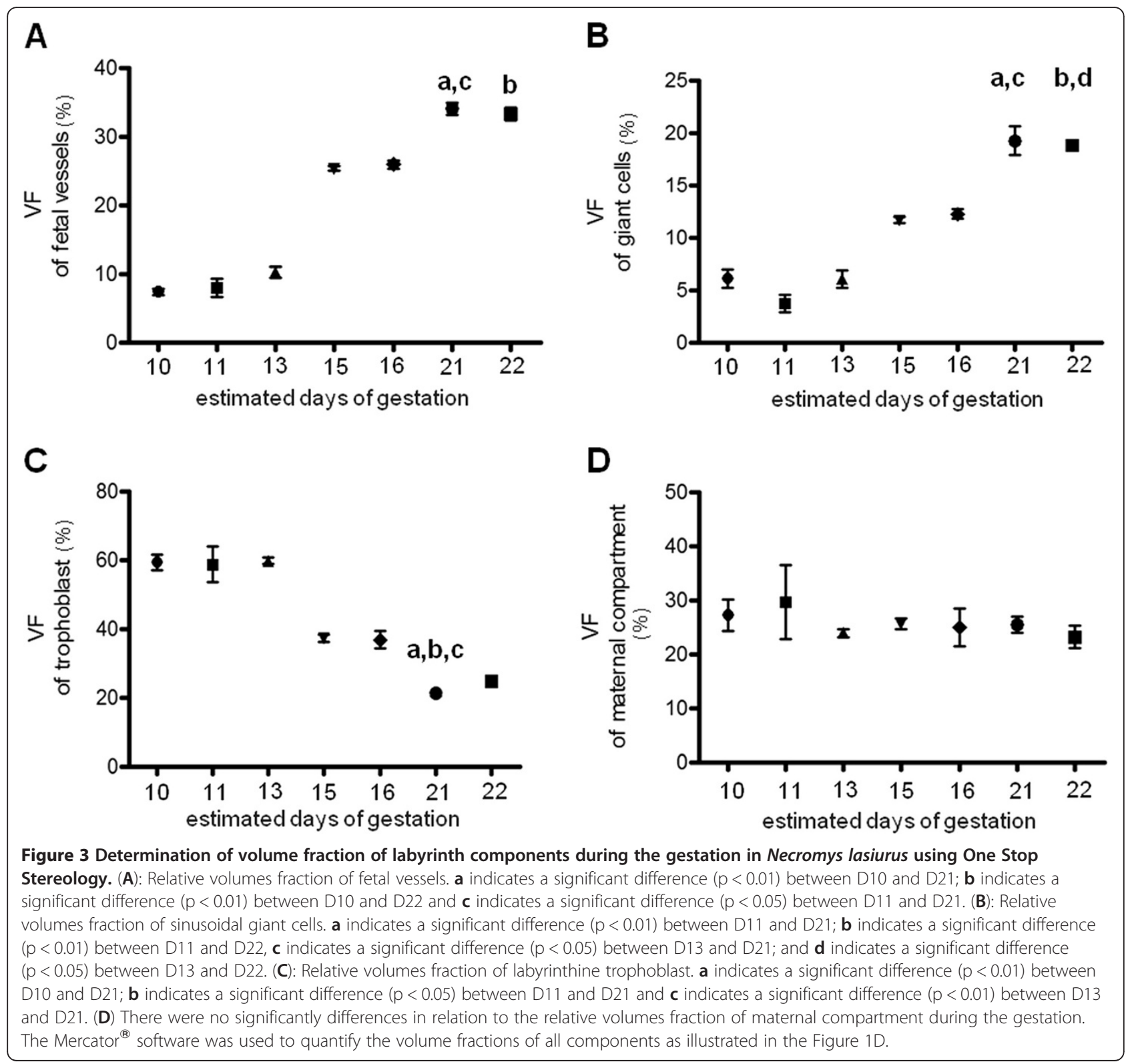


15.5 of gestation, the labyrinthine trophoblast was the relatively most abundant tissue inside the labyrinth $(41.82 \pm 0.74 \%)$ whereas the volume fraction of fetal vessels, maternal blood spaces and sinusoidal giant cells were lower $(23.66 \pm 0.44 \%, 24.48 \pm 0.85 \%$ and $9.95 \pm$ $0.33 \%$, respectively).

\section{Discussion}

Stereology is a rigorous method, based on mathematical principles and rules for counting, which enables quantitative results in a three-dimensional structure to be obtained using two dimensional samples [2].

Here, we used paraffin embedded placentae for histology and immunohistochemistry. Immunohistochemistry allowed a better identification of structural components of the labyrinth and consequently lead to a precise analysis of the volumes fractions of $N$. lasiurus and $M$. musculus domesticus placentae.

In contrast to Muridae for which qualitative and quantitative data are available in the literature, only qualitative aspects about the placenta and placentation in a few number of cricetids species were investigated [39-43]. In addition, especially Necromys lasiurus have been investigated by our group and detailed qualitative studies about the characteristics of the chorioallantoic and yolk sac placentation were performed using light microscopy, immunohistochemistry, and scanning and transmission electron microscopy $[44,49]$.

In detail, a significant increase in the absolute volume of the placenta and the main regions (labyrinth, junctional zone, and decidua) from early to mid-gestation was observed in $N$. lasiurus, followed by subsequent decrease near term. Thus, maximal placental extension was reached during mid-gestation. This is similar to what was observed in the mouse $[9,48,50]$, supporting the interpretation that general patterns of placental structure and development are largely conserved within the rodent suborder Muroidea. In contrast, the placenta grows continuously in the human, at least under normal conditions, although external factors such as multiple pregnancies and disease could influence this development [5,7,8,51,52]. The differences in growth pattern between the human on the one side and the mouse and its relatives on the other side may have an important influence during gestation. Thus, differential and growth aspects should not be uncritically investigated in mouse model. For instance, Carter [19] provided a balanced and critical discussion on the suitability of the mouse as model species in comparison for human placentation.

It is important to note, however, that the absolute volume of the mouse placenta at the end of gestation $([9,28,50,53]$, our results) was 3 -fold higher than that of $N$. lasiurus, which had a greater body mass. Placental efficiency near term was also more than 10 in the mouse $[9,53,54]$, but only 0.9 for $N$. lasiurus.

The labyrinth was the most prominent placental structure in $N$. lasiurus throughout gestation. In the mouse, at the end of gestation, the absolute volume of the labyrinth was similar to the junctional zone ([9], own results) and its relative size in comparison to the junctional zone was not very different than in $N$. lasiurus. Only in the labyrinth, the fetal capillaries and maternal blood channels are in contact; thus this area has a key role for fetomaternal exchange processes and fetal growth. We can only speculate that the low placental efficiency in sigmodont rodents limits the relative decrease of the labyrinth during pregnancy. The junctional zone contains giant cells, glycogen cells and spongiotrophoblasts (syncytial and cellular trophoblasts) $[9,26,44]$, which may have important endocrine functions in early gestation, but which may not be essential to maintain the exponentially growing fetuses towards term.

Within the labyrinth, the relative proportion of fetal vessels and sinusoidal giant cells increased, whereas that of labyrinthine trophoblast decreased and maternal blood spaces did not exhibit significant changes. These changes may contribute to meet the demands of the developing fetus for adequate nutrition and probably to compensate the low placental efficiency. In that regard, the relative increase in fetal vessels seems to be most important. Moreover, the relative reduction of the labyrinthine trophoblast layer in advanced pregnancy corresponds to a thinning of the three-layered interhemal barrier that optimizes the diffusion distance between the maternal and fetal blood systems [44]. In the mouse near term, the labyrinthine trophoblast becomes the relative most abundant tissue, whereas particularly giant cells are reduced ([9], own results). Optimization for exchange seems to be less significant compared to $N$. lasiurus, which may reflect the effective placentation in the mouse. Finally, in early mouse gestation trophoblastic giant cells maintain important functions related to invasion processes, including the modulation of hormones and growth factor activities [34,55]; their reduction towards term correlate with the establishment of the placenta and the end of invasion. Further studies are necessary to reveal additional functions that may take place especially in the labyrinth by the sinusoidal giant cells in sigmodontine rodents and that may explain the relative explosion in their relative volume during advanced pregnancy, even though trophoblast in general was reduced.

\section{Conclusion}

Though structural aspects of placentation were relatively similar in $N$. lasiurus and the mouse, the quantitative dynamics showed important differences. In particular, the low placental efficiency in $N$. lasiurus seemed to 
force a more pronounced optimization for fetomaternal exchange processes.

\section{Competing interests}

The authors declare that they have no competing interests.

\section{Authors' contributions}

POF, MAM, PCP and AT devised the study and participated in its design. POF did the practical analysis, advised by AT. MFO and POF sampled the material. AMM and POF wrote the manuscript. PCP and AT corrected the manuscript. All authors read and approved the final manuscript.

\section{Acknowledgements}

For technical support we thank Marie-Christine Aubrière, Michèle Dahirel of the Institut National de la Recherche Agronomique, Jouy-en-Josas, as well as members of the Universidade Federal Rural do Semi-Árido, Mossoró. We thank also Yves Maurin for Nanozoomer facilities. This research was supported by INRA and by grants from FAPESP (Process number: 09/53392-8).

\section{Author details}

'Department of Surgery, School of Veterinary Medicine, University of Sao Paulo, Av. Prof. Dr. Orlando Marques de Paiva, 87, Cidade Universitária, São Paulo, SP CEP 05508-270, Brazil. ²Department of Animal Science, Universidade Federal Rural do Semi-Árido, Mossoró, Rio Grande do Norte 59625-900, Brazil. ${ }^{3}$ INRA, UMR 1198 Biologie du Développement et Reproduction, Jouy-en-Josas F-78352, France. ${ }^{4}$ ENVA, Maisons-Alfort F-94704, France. ${ }^{5}$ Foundation PremUp, Paris, France.

Received: 19 November 2012 Accepted: 18 February 2013 Published: 21 February 2013

\section{References}

1. Gundersen HJ, Jensen EB: The efficiency of systematic sampling in stereology and its prediction. J Microsc 1987, 147:229-263.

2. Howard CV, Reed MG: Unbiased stereology: Three-dimensional measurement in microscopy. 2nd edition. Abingdon, Oxon: Garland Science/Bios Scientific; 2005.

3. Mayhew TM: Stereology and the placenta: where's the point? - a review. Placenta 2006, 27:S17-S25.

4. Mayhem TM, Burton GJ: Stereology and its impact on our understanding of human placental functional morphology. Microsc Res Tech 1997 38:195-205

5. Mayhew TM: Recent applications of the new stereology have thrown fresh light on how the placenta grows and develops its form. J Microsc 1997, 186:153-163.

6. Mayhew TM, Jairam IC: Stereological comparison of 3D spatial relationships involving villi and intervillous pores in human placentas from control and diabetic pregnancies. J Anat 2000, 197:263-274.

7. Mayhew TM: A stereological perspective on placental morphology in normal and complicated pregnancies. J Anat 2009, 215:77-90.

8. Higgins M, Felle P, Mooney EE, Bannigan J: McAuliffe Fm: stereology of the placenta in type 1 and type 2 diabetes. Placenta 2011, 32:564-569.

9. Coan PM, Ferguson-Smith AC, Burton GJ: Developmental dynamics of the definitive mouse placenta assessed by stereology. Biol Reprod 2004, 70:1806-1813.

10. Kannekens EM, Murray RD, Howard CV: Currie: a stereological method for estimating the feto-maternal exchange surface area in the bovine placentome at 135 days of gestation. Res Vet Sci 2006, 81:127-133.

11. Ribeiro AACM, Lacerda PMO, Melo MP, Balieiro JCC, Souza RR: Placental microstructure and efficiency in cloned bovines: a design-based stereological approach. Cell Tissue Res 2008, 333:105-114.

12. Allen WR, Wilsher S, Turnbull C, Stewart F, Ousey J, Rossdale PD, Fowden AL: Influence of maternal size on placental, fetal and postnatal growth in horse. I. Development in utero. Reproduction 2002, 123:445-453.

13. Wilsher $S$, Allen WR: The effects of maternal age and parity on placental and fetal development in the mare. Equine Vet J 2003, 35:476-483.

14. Sibbons P: The role of stereology in the study of placental transfer between fetal foal and mare. Equine Vet J 2006, 38:106-107.
15. Rutherford JN, Tardif SD: Developmental plasticity of the microscopic placental architecture in relation to litter size variation in the common marmoset monkey (Callithrix jacchus). Placenta 2009, 30:105-110.

16. Samson JE, Mari G, Dick-Jr EJ, Hubbard GB, Ferry RJ Jr, Schlabritz-Loutsevitch The morphometry of maternal-fetal oxygen exchange barrier in the baboon model. Placenta 2011, 32:845-851.

17. Cross JC, Baczyk D, Dobric N, Hemberger M, Hughes M, Simmons DG, Yamamoto H, Kingdom JCP: Genes, development and evolution of the placenta. Placenta 2003, 24:123-130.

18. Malassiné A, Frendo JL, Evain-Brion D: A comparison of placental development and endocrine functions between the human and mouse model. Hum Reprod Update 2003, 9:531-539.

19. Carter AM: Animal models of human placentation - a review. Placenta 2007, 28:S41-S47.

20. Salbaum JM, Kruger C, Zhang X, Arbour Delahaye N, Pavlinkova G, Burk DH, Kappen C: Altered gene expression and spongiotrophoblast differentiation in placenta from a mouse model of diabetes in pregnancy. Diabetologia 2011, 54:1909-1920.

21. Shrader RE, Hirsch KS, Levin J, Hurley LS: Attenuating effect of zinc on abnormal placental morphology in 6-mercaptopurine treated rats. Teratology 1978, 17:315-325.

22. Malandro MS, Beveridge MJ, Kilberg MS, Novak DA: Effect of low-protein diet-induced intrauterine growth retardation on rat placenta lamino acid transport. Am J Physiol 1996, 271:295-303.

23. Roberts CT, Sohlstrom A, Kind KL, Karl RA, Khong TY, Robinson JS, Owens $P C$, Owens JA: Maternal food restriction reduces the exchange surface area and increases the barrier thickness of the placenta in the guinea-pig. Placenta 2001, 22:177-185.

24. Levario-Carrillo M, Olave ME, Corral DC, Alderete JG, Gagioti SM, Bevilacqua E: Placental morphology of rats prenatally exposed to methyl parathion. Exp Toxicol Pathol 2004, 55:489-496.

25. Mohallem SV, Lobo DJA, Pesquero CR, Assunção JV, Andre PA, Saldiva PHN, Dolhnikoff M: Decreased fertility in mice exposed to environmental air pollution in the city of Sao Paulo. Environ Res 2005, 98:196-202.

26. Coan PM, Conroy N, Burton GJ, Ferguson-Smith AC: Origin and characteristics of glycogen cells in the developing murine placenta. Dev Dyn 2006, 235:3280-3294.

27. Hoffmann DS, Weydert CJ, Lazartigues E, Kutschke WL, Kienzle MF, Leach JE, Sharma JA, Sharma RV, Davisson RL: Chronic tempol prevents hypertension, proteinuria, and poor feto-placental outcomes in $\mathrm{BPH} / 5$ mouse model of preeclampsia. Hypertension 2008, 51:1058-1065.

28. Veras MM, Damaceno-Rodrigues NR, Caldini EG, Ribeiro AACM, Mayhew TM, Saldiva PHN, Dolhnikoff M: Particulate urban Air pollution affects the functional morphology of mouse placenta. Biol Reprod 2008, 79:578-584.

29. Coan PM, Vaughan OR, Sekita Y, Finn SL, Burton GJ, Constancia M, Fowden AL: Adaptations in placental phenotype support fetal growth during undernutrition of pregnant mice. J Physiol 2010, 588:527-538.

30. Li J, LaMarca B, Reckelhoff JF: A model of preeclampsia in rats: the reduced uterine perfusion pressure (RUPP) model. Am J Phys - Heart Circ Physiol 2012, 303:H1-H8.

31. Rennie MY, Dentmar J, Whiteley KJ, Jurisicova A, Adamson SL, Sled JG: Expansion of the fetomaternal vasculature in late gestation in strain dependent in mice. Am J Physiol - Heart Circ Physiol 2012, 15:H1261-H1273.

32. Adamson SL, Lu Y, Whiteley KJ, Holmyard D, Hemberger M, Pfarrer C, Cross $\mathrm{JC}$ : Interations between trophoblast cells and the maternal and fetal circulations in the mouse placenta. Dev Biol 2002, 250:358-373.

33. Zhang JH, Yamada AT, Croy BA: DBA-lectin reactivity defines natural killer cells that have homed to mouse decidua. Placenta 2009, 30:968-973.

34. Hu D, Cross JC: Development and function of trophoblast giant cells in the rodent placenta. Int J Dev Biol 2010, 54:341-354.

35. Senner $C E$, Hemberger M: Regulation of early trophoblast differentiation Lessons from the mouse. Placenta 2010, 31:944-950.

36. Tesser RB, Scherholz PLA, Nascimento L, Katz SG: Trophoblast glycogen cells differentiate early in the mouse ectoplacental cone: putative role during placentation. Histochem Cell Biol 2010, 134:83-92.

37. Zhang JH, Chen Z, Smith GN, Croy BA: Natural Killer cell-triggered vascular transformation: maternal care before birth? Cell Mol Immunol 2011, 8:1-11.

38. Vercruysse L, Caluwaerts S, Luyten C, Pijnenborg R: Interstitial trophoblast invasion in the decidua and mesometrial triangle during last third pregnancy in the rat. Placenta 2006, 27:22-33. 
39. Carpenter SJ: Light and electron microscopic observations on the morphogenesis of the chorioallantoic placenta of the golden hamster (Cricetus auratus). Days seven through nine of gestation). Am J Anat 1972, 135:445-476.

40. Pijnenborg R, Robertson WB, Brosens I: The arterial migration of trophoblast in the uterus of golden hamster, Mesocricetus auratus. J Reprod Fertil 1974, 40:269-280.

41. Carpenter SJ: Ultrastructural observations on the maturation of the placental labyrinth of the golden hamster (days 10 to 16 of gestation). Am J Anat 1975, 143:315-347.

42. King BF, Hastings RA: The comparative fine structure of the interhemal membrane of chorioallantoic placentas from six genera of myomorph rodents. Am J Anat 1977, 149:165-180.

43. Ferro EAV, Bevilacqua E: Trophoblastic invasion of the uterine epithelium in Calomys callosus (Rodentia, Cricetidae). J Morphol 1994, 221:139-152.

44. Favaron PO, Carter AM, Ambrosio CE, Morini AC, Mess AM, Oliveira MF, Miglino MA: Placentation in Sigmodontinae: a rodent taxon native to South America. Reprod Biol Endocrinol 2011, 9:55A.

45. Francisco AL, Magnusson WE, Sanaiotti TM: Variation in growth and reproduction of Bolomys lasiurus (Rodentia: Muridae) in an Amazonian savanna. J Trop Ecol 1995, 11:419-428.

46. Evans HE, Sack WO: Prenatal development of domestic and laboratory mammals: growth curves, external features and selected references. Anat Histol Embryol 1973, 2:11-45.

47. Lecarpentier E, Morel O, Tarrade A, Dahirel M, Bonneau M, Gayat E, EvainBrion D, Chavatte-Palmer P, Tsatsaris V: Quantification of utero-placental vascularization in a rabbit model of IUGR with three-dimensional power Dopper angiography. Placenta 2012, 33:769-775.

48. Reed MG, Howard CV, DE Yanés GS: One-stop stereology: the estimation of 3D parameters using isotropic rulers. J Microsc 2010, 239:54-65.

49. Favaron PO, Carter AM, Mess AM, Oliveira MF, Miglino MA: An unusual feature of yolk sac placentation in Necromys lasiurus (Rodentia, Cricetidae, Sigmodontinae). Placenta 2012, 33:578-580.

50. Coan PM, Angiolini E, Sandovici I, Burton GJ, Constância M, Fowden AL: Adaptations in placental nutrient transfer capacity to meet fetal growth demands depend on placental size in the mice. J Physiol 2008, 586:4567-4576.

51. van Patot MC T, Murray AJ, Beckey V, Cindrova-Davies T, Johns J, Zwerdlinger L, Jauniaux E, Burton GJ, Serkova NJ: Human placental metabolic adaptation to chronic hypoxia, high altitude: hypoxic preconditioning. Am J Physiol. Regulator, integrative and comparative physiology 2010, 298:166-172.

52. Belkacemi L, Nelson DM, Desai M, Ross MG: Maternal undernutrition influences placental-fetal development. Biol Reprod 2010, 83:325-331.

53. Coan PM, Fowden AL, Constância M, Ferguson-Smith AC, Burton GJ, Sibley CP: Disproportional effects of lgf2 knockout on placental morphology and diddusional exchange characteristics in the mouse. J Physio/ 2008 586:5023-5032.

54. Kurtz H, Zechner U, Orth A, Fundele R: Lake correlation between placenta and offspring size in mouse interspecific crosses. Anat Embryol 1999, 200:335-343.

55. Soloveva V, Linzer DIH: Differentiation of placental trophoblast giant cells requires dowregulation of p53 and Rb. Placenta 2004, 25:29-36.

doi:10.1186/1477-7827-11-10

Cite this article as: Favaron et al:: Morphometric analysis of the placenta in the New World mouse Necromys lasiurus (Rodentia, Cricetidae): a comparison of placental development in cricetids and murids. Reproductive Biology and Endocrinology 2013 11:10.

\section{Submit your next manuscript to BioMed Central and take full advantage of:}

- Convenient online submission

- Thorough peer review

- No space constraints or color figure charges

- Immediate publication on acceptance

- Inclusion in PubMed, CAS, Scopus and Google Scholar

- Research which is freely available for redistribution

Submit your manuscript at www.biomedcentral.com/submit
C Biomed Central 